\title{
What characteristics of board of directors affect Indonesian bank performance?
}

\author{
Stevanus Pangestu ${ }^{1 *}$, Christiana Fara Dharmastuti ${ }^{1}$ \\ ${ }^{1}$ Faculty of Economics and Business, Atma Jaya Catholic University of Indonesia \\ *Corresponding author E-mail: pangestu@atmajaya.ac.id
}

\begin{abstract}
The sustainability of a firm is determined by the effectiveness of its board of directors. Hambrick and Mason's Upper Echelon theory states that management characteristics could predict organizational outcomes. This study examines the effects of the characteristics of board of directors on the performance of publicly-traded banks in Indonesia. The measures of board characteristics are educational attainment, presence of independent directors, employment of foreign directors, compensation of directors, and age of directors. Our 58 firm-year observations from 2014-2015 were analyzed using fixed effects model. We find evidence that bank profitability is (i) positively affected by doctorate education of board members and (ii) negatively affected by remuneration of top executives. Based on our findings, we would suggest corporations to: comply with governmental regulations regarding the employment of independent directors, align the interest between principals and agents to eliminate agency problem, and accommodate board members with scholarships designated for academic development.
\end{abstract}

Keywords: Corporate Governance; Bank Performance; Board Characteristic; Agency Problem; Upper Echelon.

\section{Introduction}

The management is responsible for value enhancement and performance improvement in corporations. A good corporate governance system assures efficient and effective corporate practices conducted by the board of directors (BOD). Indonesian corporations follow a two-tier board structure, i.e. a definitive separation of board of commissioners (BOC) as overseer and BOD as top executives. Established in the corporate structure, general meeting of shareholders holds highest authority; they select and dismiss BOC. The BOC, which represent shareholders' interests, directly supervise BOD to ensure the effectiveness of management activities (Arifin, 2005).

Jensen (2002) states that the main objective of a firm is to maximize its value. However, achieving such objective has to be done ethically. This is where corporate governance plays it role. Rezaee (2007) argues that the role of corporate governance is to minimize agency costs and to create long-term shareholder value; focusing on responsibilities of BOD in monitoring the functions of senior executives. Kowalewski (2016) also argues that corporate governance would increase dividends. He furthermore states that during times of financial crisis, corporate governance would generate higher ROA. However, Essen, Enggelen, and Carney (2013), in their study of 1,197 firms in 26 European countries, give evidence that corporate governance practices may harm firms in certain situations. These findings lead to the question whether the benefits of good corporate governance are wide-ranging or merely fractional.

Alwi (2009) generally defines corporate governance as a system, structure, mechanism, process, or a set of rules outlining the relationship between parties in a corporation, which establishes clear entitlements and responsibilities. Whereas Shleifer \& Vishny
(1997) define corporate governance as a mechanism in which owners of companies receive their return on investments. It is the duty of BOD to make sure that corporate governance is implemented properly for the sustainability of the organization. The human resource element is crucial for fulfilling the duty of the board.

Hambrick and Mason (1984) theorized that organizational outcomes could be partially predicted by managerial background characteristics. This is called the Upper Echelon theory. For the sake of maintaining sustainable competitive advantage, certain characteristics would be required from the members of the BOD. This has been proven by Mohamed, Jarboui, Baccar, and Bouri (2015), who found that these characteristics could largely affect firm values.

One of the characteristics is intelligence. Caplan and Miller (2010) drew conclusion that education is proxy for intelligence. There have been previous studies showing positive relationship between educational attainment and firm performance such as King, Srivastav, and Williams (2016). However, Darmadi (2013) stated that in Indonesia, high-performing firms were founded and managed by people who were not highly-educated. Lindorff \& Jonson (2013) also found that there were no relationship between business educations of Australia's top 200 CEOs and firm financial performance.

Another demographic factor that could influence the firm performance is the director's age, as discovered by Amran, Yusof, Ishak, and Aripin (2014). Ting, Azizan, and Kweh (2015) found that younger CEOs are more likely to be aggressive and risk-taking. While Cline \& Yore (2016) found that the age of S\&P firm CEOs were negatively related to firm value and performance.

The financial industry is one of the most exposed industries due to the occurences of global financial crisis. According to the Financial Services Authority of Indonesia (2015), the Finance industry 
deeply affects the dynamic of the country's economy not only as financier for producers and consumers, but also as an institution of wealth storage. The prioritized economic agenda of Indonesia is the optimization of SME, with banks front-lining this effort because they are still by far the most utilized and trusted financial institution in Indonesia at $74 \%$. The good implementation of corporate governance becomes particularly important in the banking sector.

Based on the importance of BOD in implementing good corporate governance and increasing firm value, supplemented by previous empirical result inconsistencies, we would like to reassess the effects of educational attainment, age of top executives, and other board characteristics on bank performance. To our knowledge, this study would be among the first to focus specifically on bank performances. It has been rare in nature due to the difference of regulations compared to the other non-financial counterparts.

\section{Literature review}

According to the Modern Corporation and Private Property (1932), as written by Berle and Means (as referenced in Kang \& Sorensen, 1999), it is pronounced that there should be a separation of owners and managers within corporations. The division of control and ownership would institute firms as autonomous entities. Managers operate the firm and maintain its going-concern, while owners perform control functions and invest in capital.

The division of ownership and control results in an agency relationship. This relationship occurs when principals (owners) entrust their power and authority to the employed agents (management). This arrangement between different parties in corporations is referred by Jensen and Meckling (1976) as nexus of contracts.

Corporate governance is required for designing management strategies, creating firm value, and resolving agency conflicts. According to Hart (1995), the surge of corporate governance issues has been caused by the conflict of interests within the organization and the costs of transacation arising from unresolved agency problem (unsolvable through contracts). He states furthermore that through efficient corporate governance, the market economy can be achieved.

Rezaee (2007) expresses that corporate governance structure consists of seven functions: oversight, managerial, compliance, internal audit, advisory, external audit dan monitoring. Firm performance is heavily affected by three out of the seven corporate governance functions:

i) Oversight, conducted by the board of commissioners.

ii) Managerial, executed by the management or top executives, and.

iii) Monitoring, performed by the shareholders.

Therefore, an effective corporate governance depends on the division of power between the aforementioned three parties. Additionally, internal and external mechanisms of corporate governance have to be installed not only to organize and control the relationship between all parties in corporate governance, but also to design remuneration policies for the management. Only then, values can be created for shareholders, and the interests of other stakeholders can be secured.

One approach of internal mechanism that can address conflict of interests is applying contracting theory. Jensen (2002) indicates that agency theory is a useful tool for analyzing determinants in constructing complex contractual arrangements. These contracts comprise compensation and reward plans for agents, which could be based on certain performance measures. Such legal agreements reflect the division of management decisions and control decisions.

Our study focuses on the management function in corporate governance that has been delegated from the shareholders to the care of the agents: the resources that operate the organization.

\subsection{Education and bank performance}

Jarboui, Baccar, and Bouri (2015) found that CEO's technical education could increase firm value. By implication, the education of all BOD members could also affect firm values. Mohamed, Darmadi (2013), in his study of listed Indonesian companies, found that CEOs holding degrees from prestigious domestic universities performed significantly better than those without such qualifications. Whilst in the United Kingdom, King, Srivastav, and Williams (2016) found that educational attainment influenced performances of banks; those that were led by CEOs with MBAs outperform their peers.

Furthermore, according to the Upper Echelon theory by Hambrick and Mason (1984), intellectual competence and high knowledge could be indicated by a higher education level. Therefore, we formulate that educational attainment could affect firm performance: $\mathrm{H}_{1}$ : Education of BOD members positively influence bank performance

\subsection{Age and bank performance}

Shen (2014) showed that adversity quotient increases with age, enhanced through learning. The older senior executives are, the more experience they possess. These experiences are not only industrial and professional in nature, but also personal.

Ben Mohamed, Baccar, Fairchald, and Bouri (2012) showed that older CEOs were more rational. Ben Mohamed, Jarboui, Baccar, and Bouri (2015) also found that CEO's age had positive effect on firm value. We formulate the second hypothesis as follows:

$\mathrm{H}_{2}$ : Age of BOD members positively influence bank performance

\subsection{Independent directors and bank performance}

Indonesian Stock Exchange Regulation Number I.A and Circular Letter No. SE-00001/BEI/02-2014 dictate that listed companies should have at least one independent director. Independent director is an executive, who is not affiliated with controlling shareholders, directors, commissioners, and not employed by other corporations as director. He or she has to be a professional from outside the company and is chosen to represent and protect the interests of the minority shareholders

Liu, Miletkov, Wei, and Yang (2015) found that in China, independent directors had positive effect on firm operating performance. Cavaco, Crifo, Reberioux, and Roudaut (2017) also supported a similar finding that independent directors have even higher abilities than affiliated ones. Zhu, Ye, Tucker, and Zhan (2016) suggested empowering independent directors that could lead to more effective monitoring and higher firm value. Based on previous studies and the possibility that board independence could also reduce agency cost, we formulate:

$\mathrm{H}_{3}$ : Independent directors positively influence bank performance

\subsection{Existence of expatriates and bank performance}

The recruitment of expatriates is expected to bring foreign and more developed knowledge and skills to the corporate asset. $\mathrm{Mu}$ ravyev (2017) found that proportion of foreign directors were positively related to company performance. Tee, Aik, and Lim (2016) also found that increase in percentage of foreign directors on the BOD significantly improved profitability.

The employment of expatriates would also directly enhance the board's diversity, therefore we hypothesize:

$\mathrm{H}_{4}$ : The existence of foreign directors positively influences bank performance

\subsection{Compensation and bank performance}

One of the sources of agency costs is the divergence of interests between the firm owners and the employed top executives. According to agency theory, this issue could be reduced by paying 
the management executives with compensation, as a reward for good financial performance.

Gao \& $\mathrm{Li}$ (2015) found that CEO pays were positively related to firm accounting performance. Subekti (2015) also gave evidence to positive effect of executive compensation on ROA. Shim \& Kim (2015) showed that American CEOs' total compensation is significantly and positively related to ROA. These findings show that compensation could stimulate high firm performance, as well as align the agent's interests with the principal's.

$\mathrm{H}_{5}$ : Executive compensation positively influences bank performance

\section{Methodology}

Our research sample consists of publicly-traded banks in the Indonesian Stock Exchange. After a series of eliminations, 29 banks were observed for a period of 2 years, resulting in 58 firm-year observations. The inclusion criteria for our sample were as follows:

i) Banks listed in the Indonesian Stock Exchange, and.

ii) Banks with comprehensive data, specifically the profile information of BOD, for the financial years 2014 and 2015 . Data were extracted from annual reports and company websites.

The response variable of this research is bank performance. The measure is bank profitability adjusted for industry trends: the bank's Return on Assets minus the mean Return on Assets of all the other banks on an annual basis. This is done in order to eliminate industry-wide component that is uncontrollable to the directors and unrelated to their talents (King, Srivastav, \& Williams, 2016). Our data were then analyzed using descriptive and panel data regression models on EViews software.

Table 1: Variable Definition

\begin{tabular}{|c|c|c|}
\hline Variable & Definition & Formula \\
\hline $\begin{array}{l}\text { Education } \\
\text { (EDU) }\end{array}$ & $\begin{array}{l}\text { Education of board } \\
\text { members. Proportion of } \\
\text { those with postgraduate } \\
\text { (doctorate) degrees }\end{array}$ & $\begin{array}{l}\text { Number of directors with } \\
\text { doctorate degree/Total } \\
\text { number of directors }\end{array}$ \\
\hline $\begin{array}{l}\text { Age of direc- } \\
\text { tors (AGE) }\end{array}$ & $\begin{array}{l}\text { Average age of board } \\
\text { members }\end{array}$ & $\begin{array}{l}\text { Total age of all directors/ } \\
\text { Total number of directors }\end{array}$ \\
\hline $\begin{array}{l}\text { Independent } \\
\text { directors (IN- } \\
\text { DIE) }\end{array}$ & $\begin{array}{l}\text { Proportion of board } \\
\text { members who are unaf- } \\
\text { filiated }\end{array}$ & $\begin{array}{l}\text { Number of independent } \\
\text { directors/ Total number of } \\
\text { directors }\end{array}$ \\
\hline $\begin{array}{l}\text { Foreign direc- } \\
\text { tors (EXPAT) }\end{array}$ & $\begin{array}{l}\text { Proportion of board } \\
\text { members whose nation- } \\
\text { ality is not Indonesian }\end{array}$ & $\begin{array}{l}\text { Number of foreign direc- } \\
\text { tors/ Total number of } \\
\text { directors }\end{array}$ \\
\hline $\begin{array}{l}\text { Directors' } \\
\text { compensation } \\
\text { (PAY) }\end{array}$ & $\begin{array}{l}\text { Proportion of top execu- } \\
\text { tive's compensation } \\
\text { relative to the firm's } \\
\text { total employee expenses }\end{array}$ & $\begin{array}{l}\text { Total management com- } \\
\text { pensation/Total employee } \\
\text { expenses }\end{array}$ \\
\hline $\begin{array}{l}\text { Firm perfor- } \\
\text { mance (PERF) }\end{array}$ & $\begin{array}{l}\text { Return on asset; the } \\
\text { profit achieved from the } \\
\text { firm's resources }\end{array}$ & $\begin{array}{l}\text { Return on assets - Aver- } \\
\text { age ROA for banking } \\
\text { sector }\end{array}$ \\
\hline
\end{tabular}

\section{Findings \& discussion}

Table 2: Descriptive Statistics

\begin{tabular}{llllllc}
\hline & $\begin{array}{l}\text { EDU } \\
(\%)\end{array}$ & $\begin{array}{l}\text { INDIE } \\
(\%)\end{array}$ & $\begin{array}{l}\text { EXPAT } \\
(\%)\end{array}$ & $\begin{array}{l}\text { PAY } \\
(\%)\end{array}$ & $\begin{array}{l}\text { AGE } \\
(\text { year })\end{array}$ & $\begin{array}{c}\text { PERF } \\
(\%)\end{array}$ \\
\hline Mean & 1.949 & 9.223 & 9.561 & 6.5355 & 52.37 & 0.3006 \\
Maximum & 40.0 & 100.0 & 50.00 & 19.225 & 58.00 & 3.654 \\
Minimum & 0.00 & 0.00 & 0.00 & 0.524 & 47.00 & -1.474 \\
Std. Dev. & 6.862 & 20.644 & 14.399 & 4.546 & 3.067 & 1.2504 \\
$\begin{array}{l}\text { Observa- } \\
\text { tions }\end{array}$ & 58 & 58 & 58 & 58 & 58 & 58 \\
\hline
\end{tabular}

Our descriptive statistics (refer to Table 2) result shows that only 6 banks employed board members holding doctorate degrees, with the BOD of PT. Bank Yudha Bhakti Tbk. being the most-educated at $40 \%$.

Despite the compulsory nature of independent directors in Indonesia, its implementation is still subpar: INDIE shows an average of
9.2\%. PT. Bank Agris Tbk. led the banking sector with 100\% independent BOD. As for foreign directors, EXPAT averaged 9.56\%. Board members of PT. Bank QNB Kesawan were 50\% expatriates. There were also 19 corporations that did not employ foreigners as their directors.

When it comes to compensation of directors, BOD of PT. Bank Dinar Indonesia Tbk. took the largest chunk of the bank's employee expenses at $19.22 \%$, while PT. Bank Rakyat Indonesia Tbk took the lowest at $0.52 \%$. While the sector averaged in $6.54 \%$.

The average age of Indonesian bank directors was 52.37. PT. Bank Pan Indonesia Tbk. had the oldest board members; averaging in 57 years old, while PT. Bank Pembangunan Daerah Jawa Barat Tbk. had the youngest members at an average of 47 years of age. Our data shows that Indonesian board members were middleaged or older.

Lastly, PT. Bank Rakyat Indonesia Tbk. generated the highest $P E R F$ at $3.65 \%$, while the bank with the lowest PERF was PT. Bank Agris Tbk.

Table 3: Redundant Fixed Effects - Likelihood Ratio Testing Redundant Fixed Effects Tests

\begin{tabular}{llll}
\hline Test cross-section fixed effects & & & \\
Effects Test & Statistic & d.f. & Prob. \\
Cross-section F & 5.954673 & $(28,24)$ & 0.0000 \\
Cross-section Chi-square & 120.222948 & 28 & 0.0000 \\
\hline
\end{tabular}

Prior to running the regression to test our hypothesis, we had to determine which panel data estimator would be best for our model by conducting Redundant Fixed Effects test and Hausman test.

The redundant fixed effects-likelihood ratio testing shows a pvalue lower than 0.05 level of significance. It can be concluded that fixed effects estimator would be better than ordinary, pooled OLS and that it can be utilized in our data analysis. However, Hausman test was also performed to determine whether random effects estimator would be better than fixed estimator.

Table 4: Hausman Test

\section{Correlated Random Effects - Hausman Test}

Test cross-section random effects

\begin{tabular}{llll} 
Test Summary & Chi-Sq. Statistic & $\begin{array}{l}\text { Chi-Sq. } \\
\text { d.f. }\end{array}$ & Prob. \\
Cross-section random & 2.591739 & 5 & 0.7626 \\
\hline
\end{tabular}

Table 4 shows a p-value of 0.7626 , greater than $5 \%$ level of significance. We can conclude that random effects estimator would be better and more efficient than fixed estimator for our model. Table 5 summarizes the results of panel data regression using random effects estimator:

\begin{tabular}{lllll}
\multicolumn{5}{c}{ Table 5: Panel Data Regression Results } \\
\hline Variable & Coefficient & Std. Error & t-Statistic & Prob. \\
\hline C & 0.841873 & 2.775097 & 0.303367 & 0.7628 \\
EDU & 0.032237 & 0.016942 & 1.902765 & $0.0626^{* *}$ \\
INDIE & -0.009913 & 0.008744 & -1.133765 & 0.2621 \\
EXPAT & -0.011382 & 0.013126 & -0.867120 & 0.3899 \\
PAY & -0.096628 & 0.043051 & -2.244498 & $0.0291^{*}$ \\
AGE & 0.004164 & 0.053514 & 0.077804 & 0.9383 \\
Effects Specification & & & & \\
& & & S.D. & Rho \\
Cross-section random & & & 0.0394600 & 0.7512 \\
Idiosyncratic random & & & 0.2488 \\
Weighted Statistics & & & \\
R-squared & 0.164723 & Mean dependent var & 0.113296 \\
Adjusted R-squared & 0.084408 & S.D. dependent var & 0.606844 \\
S.E. of regression & 0.580668 & Sum squared resid & 17.53315 \\
F-statistic & 2.050967 & Durbin-Watson stat & 1.969176 \\
Prob(F-statistic) & 0.086663 & & \\
* corresponds to 5\% level of significance & \\
** corresponds to 10\% level of significance & & \\
\hline
\end{tabular}

\section{a) Education \& Bank Performance}

$E D U$ shows a p-value of .0626, therefore accepting $\mathrm{H}_{1}$ at .1 level of significance. Educational attainment of BOD, which was measured with doctorate degrees, positively affects bank performance. 
Board members with higher educational qualifications are considered to possess higher intelligence and management capabilities. Gottesman and Morey (2006a) argued that managers with higher education would be more innovative and adaptive, they also possess other characteristics that positively influence bank performance. Moreover, the higher the education, the more problemsolving methods that can be applied. Our finding supports the Upper Echelon theory and is consistent with King, Srivastav, and Williams (2016) and Akpan and Amran (2014), who found that educational attainment affects firm performance; those who have received higher education would possess knowledge, experience, and the skills to manage performance and organizational affairs.

b) Independent directors and bank performance

The p-value for INDIE is .2621 and consequently, $\mathrm{H}_{2}$ was rejected. Our finding is in line with Adams (2016). The insignificant result may arise from the fact that many banks still have not installed independent, unaffiliated board members. It should also be noted that the Indonesian Financial Services Authority had only introduced this regulation in September of 2014.

c) Foreign directors and bank performance

EXPAT shows a p-value of .3899 , therefore rejecting $\mathrm{H}_{3}$. The negative and insignificant effect of this variable could arise from the assumption that expatriate existence would contribute international experience and perspective to the company, and yet it achieved the contrary. This finding is line with Masulis (2012), who gave evidence that while foreign BOD members bring in diversity, expertise, and additional perspective, they bring down profitability Decrease in ROA can be caused by (i) increase in expenses or decrease in revenues, or (ii) the acquisition of assets that do not generate yield. This may be triggered by the shareholders or commissioners overestimating the capabilities of the expatriates, causing increase in remuneration expenses. Moreover, expatriates are compensated more than local human resources.

d) Directors' compensation and bank performance

$P A Y$ has a p-value of .029. However, even though the p-value is lower than the .05 significance level, the effect of directors' compensation on bank performance was found to be negative. Thus, $\mathrm{H}_{4}$ was rejected. This is in line with Matousek (2015), who found that executive compensation negatively influences banks' operating efficiency.

Remuneration of BOD is accounted for in expenses, which would hinder firm performance. Costs of remuneration are also a function of agency conflict: directors are so focused on their own interests in pursuing incentives that management decisions negatively affect the company as a whole.

e) Age of directors and bank performance

$A G E$ shows a p-value of .9383 , which rejected our last alternative hypothesis. The absence of this explanatory variable's effect may arise from the relatively old age of the directors. The majority of Indonesian bank board members can be categorized as seniors. Older ages are often considered to be synonymous with work and life experience, wider network, and independence, but our finding shows that it does not significantly influence firm performance. However, if BOD had younger members, they would tend to be more innovative, efficient, and responsive toward risks (Ness, Miesing, \& Kang, 2010).

\section{Conclusion}

Our findings show that there are characteristics of board of directors that influence firm performance in the Indonesian banking sector:

1) Education positively affects bank performance.

2) Remuneration of top executives negatively affects bank performance.

3) Age of directors and the existence of independent directors and foreign directors do not significantly influence bank performance.

\section{Implications}

- Corporations should consider accommodating their top executives to enrol in higher education institutions. In doing so, they could stimulate organizational improvement. Other than recruiting directors that possess expertise in their fields and high educational attainment, shareholders would still need to provide management with trainings and scholarships designated for academic development.

- A priori, independent directors are favorable for corporations. However, our findings show that there are only the least amount of firms with independent directors. We would suggest organizations across the nation to conform to government regulation and employ independent directors.

- When it comes to remuneration or compensation, there needs to be an alignment of interests between principals and agents. Contracts should be constructed by putting emphasis on objectives, so that the remuneration that would be rewarded accordingly. As a result, the costs of remuneration would correspond with the realized organizational performance.

\section{References}

[1] Akpan, E. and Amran, N. 2014. Board characteristics and company performance: Evidence from Nigeria, Journal of Finance and Accounting. 2(3): 81-89 https://doi.org/10.11648/j.jfa.20140203.17.

[2] Alwi Syafaruddin. 2009. Dividend and Debt Policy as Corporate Governance mechanism: Indonsian Evidence, Jurnal Pengurusan 29. 111-127

[3] Amran, N.A. Yusof, M.A.M., Ishak, R., and Aripin, N. (2014). Do Characteristics of CEO and Chariman InfluenceGovernmentLinked Companies Performance?. Procedia-Social and Behavioral Sciences.

109

799-803. https://doi.org/10.1016/j.sbspro.2013.12.546.

[4] Arifin. 2005. "Peran akuntan dalam mengeakkan prinsip good corporate governance pada perusahaan di Indonesia (Tinjauan perspektif teori keagenan)", Paper presented on dissertation defense, Universitas Diponegoro, Semarang

[5] Berle, A.A. and Means G.C. (1932). The Modern Corporation and Private Property. New York: Harcourt, Brace \& World

[6] Caplan, B. and Miller, S.C. (2010). Intelligence Makes People Think like Economists: Evidence from the General Social Survey".

38 636-647. https://doi.org/10.1016/j.intell.2010.09.005

[7] Cavaco, S., Crifo, P., Reberioux, A., and Roudaut, G. (2017) Independendt Directors: Less Informed but Better Selected than Affiliated Board Members?. Journal of Corporate Finance. 43. 106-121. https://doi.org/10.1016/j.jcorpfin.2017.01.004.

[8] Cline, B.N. and Yore, A.S. (2016). Silverback CEOs: Age, Experience, and Firm Value. Journal of Empirical Finance. 35 169-188. https://doi.org/10.1016/j.jempfin.2015.11.002.

[9] Darmadi, S. (2013). Board Members' Education and Firm Perormance: Evidence from a Developing Company. International Journal of Commerce and Management. 23(2). 113-135. https://doi.org/10.1108/10569211311324911.

[10] Essen, M., Engelen, P.J., and Carney, M. (2013) Does 'good' corporate governance help in a crisis? The impact of country- and firm-level governance mechanisms in the European financial crisis. Corporate Governance .21(3).201-224. https://doi.org/10.1111/corg.12010.

[11] Hambrick, D.C. and Mason, P.A. (1984) Upper Echelons: The Organization as a Reflection of Its Top Managers. The Academy of Management Review. 9(2). 193-206.

[12] Hart, O. (1995). Corporate Governance: Some Theory and Implications. The Economic Journal. 105(430). 678-689. https://doi.org/10.2307/2235027.

[13] Jensen, M.C. (2002). Value Maximization, Stakeholder Theory, and the Corporate Objective Function. Business Ethics Quaterly. 12(2) 235-256. https://doi.org/10.2307/3857812.

[14] Jensen, M.C. and Meckling, W.H. (1976). Theory of the Firm: Managerial Behavior, Agency Costs, and Ownership Structure. Journal of Financial Economics. 3. 305-360. https://doi.org/10.1016/0304-405X(76)90026-X.

[15] Kang, D.L. and Sorensen, A.B. (1999). Ownership Organization and Firm Performance. Annual Review of Sociology. 25. 121-144. https://doi.org/10.1146/annurev.soc.25.1.121. 
[16] King, T., Srivastav, A., and Williams, J. (2016). What's in an Education? Implications of CEO education for Bank Performance. Jorunal of Corporate Finance, https://doi.org/10.1016/j.jcorpfin.2016.01.003.

[17] Kowalewski, O. (2016) "Corporate governance and corporate performance: financial crisis (2008)", Management Research Review. 39(11).1494 - 1515.

[18] Lindorff, M. and Jonson, E.P. (2013). CEO Business Education and Firm Financial Performance: A Case for Humility rather than Hubris. Education + Training. 55(4/5). 461-499. https://doi.org/10.1108/00400911311326072.

[19] Liu, Y. Miletkov, M., Wei, Z., and Yang, T. (2015). Board Independence and Firm Performance in China. Journal of Corporate $\begin{array}{ll}\text { Finance. } & 30 . \\ 223-244 .\end{array}$ https://doi.org/10.1016/j.jcorpfin.2014.12.004.

[20] Mohamed, B. E., Jarboui, S., Baccar, A., and Bouri, A. (2015). On the effect of CEOs' personal characteristics in transport firm value? A stochastic frontier model. Case Study Transportation Policy. https://doi.org/10.1016/j.cstp.2015.01.001.

[21] Mohamed, B.E., Baccar, A., Fairchild, R., Bouri, A., 2012. Does corporate governance affect managerial optimism: evidence from NYSE panel data firms. International Journal Euro-Mediterranean Studies. 5(1), 41-56. https://doi.org/10.1007/s40321-012-0004-6.

[22] Muravyev, A. (2017). Boards of Directors in Russian Publicly Traded Companies in 1998-2014: Structure, Dynamics and Performance Effects. Economic Systems. https://doi.org/10.1016/j.ecosys.2016.12.001

[23] Financial Services Authority. (2016). Master Plan Sektor Jasa Keuangan Indonesia Periode 2015-2019. Jakarta: OJK.

[24] Rezaee, Z. (2007). Corporate Governance Post-Sarbanes-Oxley: Regulations, Requirements, and Integrated Processes. New Jersey: John Wiley \& Sons.

[25] Shen, C.Y. (2014). A Study Investigating the Influence of Demographic Variables on Adversity Quotient. The Journal of Human Resource and Adult Learning. 10(1). 22-32.

[26] Shleifer, A. and Vishney, R.W. (1997). A Survey of Corporate Covernance. The Journal of Finance. 52(2). 737-783. https://doi.org/10.1111/j.1540-6261.1997.tb04820.x.

[27] Shim, E.D. and Kim, E. (2015), an Empirical Examination of the Relationship between Top Executive Compensation and Firm Performance in the Post Sarbanes-Oxley Period. Advances in Management Accounting (Advances in Management Accounting. 25. $207-228$ https://doi.org/10.1108/S1474787120150000025007.

[28] Subekti, I. and Sumargo, D.K. (2015). Family Management, Executive Compensation, and Financial Performance of Indonesian Listed Companies. Procedia - Social and Behavioral $\begin{array}{lllll}\text { Sciences. } & 211 . & 578 & - & 584\end{array}$ https://doi.org/10.1016/j.sbspro.2015.11.076.

[29] Tee, P.L., Aik, N.C., Lim, C.S. (2015). Foreign ownership, foreign directors, and the profitability of Malaysian listed companies. Procedia - Social and Behavioral Sciences. 219. $580-$ 588

[30] Ting, I.W.K., Azizan, N.A.B., and Kweh, Q.L. (2015). Upper Echelon Theory Revisited: The relationship between CEO Personal Characteristics and Financial Leverage Decision. Procedia - Social and Behavioral Sciences. 195. 686 - 694. https://doi.org/10.1016/j.sbspro.2015.06.276.

[31] Zhu, J., Ye, K., Tucker, J.W., Chan, and Chan, J. (2016). Board hierarchy, independent directors, and firm value: Evidence from China, Journal of Corporate Finance. 41. 262-279, https://doi.org/10.1016/j.jcorpfin.2016.09.009. 